\title{
IMPLEMENTASI PEMBERIAN VITAMIN A BAGI IBU NIFAS DI KOTA PALU DAN KABUPATEN SIGI
}

\author{
Implementation of Vitamin A Provisions of Mother Postpartum In Palu City and Sigi \\ District
}

\author{
Taqwin*, Lisnawati, Sumiaty, Fahmi Hafid \\ Poltekkes Kemenkes Palu \\ *(taqwin.sahe78@gmail.com)
}

\begin{abstract}
ABSTRAK
Pemerintah Indonesia memberikan kapsul Vitamin A 200.000 IU untuk ibu nifas. Tujuan penelitian ini untuk mengetahui Implementasi pemberian Vitamin A Ibu Nifas di Kota Palu dan Kabupaten Sigi. Teknik Sampling dengan proportional multi stage random sampling, Penelitian dilaksanakan diwilayah kerja Dinas Kesehatan Kota Palu dan Kabupaten Sigi tanggal 02 Agustus hingga 15 September 2017. Sampel sebanyak 384 responden. Hasil penelitian menunjukkan responden berusia reproduktif 20-35 tahun (80,7\%) berpendidikan sekolah menengah umum 50\%, bekerja sebagai ibu rumah tangga 81,0\%. Implementasi pemberian Vitamin A Ibu Nifas di Kota Palu dan Kabupaten Sigi sebesar 33,3\%. Bidan merupakan profesional Kesehatan yang paling berperan dalam pemberian Vitamin A ibu nifas $(95,4 \%)$. Dari 130 orang, responden yang segera mengonsumsi vitamin A setelah melahirkan sebesar 76,2\%, 6 jam setelah melahirkan 12,3\%. Jumlah vitamin A yang diasup secara lengkap 2 kapsul per orang sebesar $66,9 \%$. Cara mengonsumsinya pada umumnya sudah benar yaitu 1 kapsul hari pertama dan 1 kapsul hari berikutnya sebesar 56,9\%. Disarankan agar pemberian kapsul Vitamin A Ibu Nifas tetap dijalankan terutama pada kelompok rentan yaitu ibu yang berpendidikan dan berpendapatan rendah. Temuan ini dapat disosialisasikan sebagai upaya mencegah kekurangan Vitamin A pada ASI ibu yang menyusui. Konsumsi minyak goreng terfortifikasi vitamin A dapat membantu memenuhi kebutuhan vitamin A pada ibu nifas terutama di kalangan wanita di komunitas berpenghasilan rendah.

Kata kunci : Kapsul Vitamin A, Ibu Nifas
\end{abstract}

\section{ABSTRACT}

The Indonesian government provides 200,000 IU Vitamin A capsules for postpartum mothers. The aim of this study was to determine the implementation of the provision of Vitamin A postpartum mothers in Palu City and Sigi Regency. Sampling technique with proportional multi-stage random sampling, the study was conducted in the Health Department of the City of Palu and Sigi Regency from 2 August to 15 September 2017. The sample was 384 respondents. The results showed respondents aged 20-35 years of reproductive (80.7\%) had a high school education of $50 \%$, worked as a housewife $81.0 \%$. Implementation of provision of Vitamin A for postpartum mothers in Palu City and Sigi Regency by $33.3 \%$. Midwives are health professionals who play a major role in the delivery of Vitamin A postpartum mothers (95.4\%). Of 130 people, 76.2 per cent of respondents took vitamin A immediately after giving birth, 12.3 per cent 6 hours after giving birth. The total amount of vitamin A that is consumed in 2 capsules per person is $66.9 \%$. How to consume it in general is correct, namely 1 capsule the first day and 1 capsule the next day by 56.9\%. It is recommended that the provision of Vitamin A capsules for Postpartum Mother is still carried out especially in vulnerable groups, namely educated and low-income mothers. This finding can be socialized as an effort to prevent Vitamin A deficiency in breastfeeding mothers. Consumption of vitamin A fortified cooking oil can help meet the needs of vitamin $A$ in postpartum mothers especially among women in low income communities.

Keywords : Vitamin A Capsules, Postpartum 


\section{PENDAHULUAN}

Menyusui diharapkan dapat memenuhi kebutuhan bayi di bulan-bulan awal kehidupan. Namun, jika ibunya kekurangan gizi bayi tidak menerima semua zat gizi dibutuhkan. Vitamin A penting untuk kekebalan dan membantu bayi tetap sehat. Jika ibu tidak memiliki asupan vitamin A yang cukup dalam makanannya, bayi mungkin juga tidak menerima cukup $\mathrm{ASI}^{(1)}$. Faktanya kebutuhan Vitamin A sulit untuk dipenuhi dalam asupan ibu menyusui yang direkomendasikan ${ }^{(2)}$. Ketidakcukupan Vitamin A bahkan $>40 \%{ }^{(3)}$ dan dipedesaan asupan vitamin A ibu menyusui kurang dari $60 \%{ }^{(4)}$. Penelitian Matamoros menunjukkan 50\% dari 79 sampel ibu, kandungan vitamin A dalam ASI tidak memenuhi rekomendasi kebutuhan untuk bayi ${ }^{(5)}$. Prevalensi defisiensi vitamin A lebih tinggi $(6,9 \%)$ pada kelompok berpenghasilan rendah dibanding pada kelompok berpenghasilan tinggi $(3,7 \%)^{(6)}$

Suplementasi Vitamin A dalam masa nifas meningkatkan konsentrasi serum retinol dan ASI, namun ini hanya relevan ketika konsentrasi serum retinol ibu sebelumnya rendah $^{(7)}$ Kurangnya efek pada kematian ibu dan bayi serta terhadap morbiditas, suplementasi vitamin A pascapersalinan ibu menawarkan manfaat yang masih terbatas ${ }^{(1,8)}$. Penelitian Tomiya et all menunjukkan tidak ada perbedaan yang signifikan antara konsentrasi retinol dalam ASI antara kelompok 400.000 IU vs $200.000 \mathrm{IU}^{(9)}$.

Sejak tahun 2016, Suplemen Vitamin A pada wanita postpartum untuk pencegahan morbiditas dan mortalitas ibu dan bayi tidak dianjurkan $^{(10)}$ namun di Indonesia, pemberian kapsul vitamin A merah 200.000 IU tetap diberikan kepada ibu nifas ${ }^{(11)}$. Ibu nifas adalah ibu yang baru melahirkan sampai 6 minggu setelah melahirkan ${ }^{(12)}$. Suplementasi Vitamin A periode postpartum merupakan cara untuk meningkatkan keamanan perawatan ibu-anak ${ }^{(13)}$ dan diyakini suplementasi memiliki dampak positif pada status vitamin $\mathrm{A}$ ibu ${ }^{(14)}$. Tujuan penelitian ini untuk menganalisis implementasi pemberian Vitamin A Ibu Nifas di Kota Palu dan Kabupaten Sigi.

\section{METODE PENELITIAN}

Penelitian deskriptif kuantitatif dengan desain potong lintang. Penelitian dilakukan di Wilayah Kerja Dinas Kesehatan Kota Palu dan Kabupaten Sigi tanggal 02 Agustus-15 September 2017. Populasi adalah ibu nifas kedua kabupaten. Sampel sebanyak 384 orang, menggunakan teknik multistage proportional random sampling.

$\mathrm{n}=\frac{Z \alpha^{2} P(1-P)}{d^{2}}$

Keterangan :

$\mathrm{n}$ =jumlah sampel minimal yang diperlukan

$\mathrm{P}=$ proporsi tanpa penelitian sebelumnya.

$\mathrm{Z}=$ nilai standar normal $(1,96)$ batas kepercayaan

$\mathrm{d}=$ Tingkat ketelitian 5\%

$\mathrm{n}=\frac{Z \alpha^{2} P(1-P)}{d^{2}}$

$\mathrm{n}=\frac{1,96^{2} x 0,356(1-0,356)}{0,05^{2}}$

$\mathrm{n}=\frac{3,8416 \times 0,05 \times 0,05}{0,0025}$

$\mathrm{n}=384,16$ dibulatkan menjadi 384 sampel.

Karakteristik responden meliputi umur, pendidikan dan pekerjaan. Variabel penelitian meliputi pemberian kapsul, petugas pemberi, tempat pemberian, metode minum, morbiditas ibu nifas dan anaknya. Kuesioner yang digunakan telah diujicobadan pengumpulan data dilakukan oleh enumerator yang telah dilatih sebelumnya. Analisa data secara univariat menggunakan distribusi frekuensi dan bivariat menggunakan Chi-square.

\section{HASIL}

Responden sebagian besar berdomisili di wilayah Kota Palu sebesar 80,7\% dan selebihnya 19,3\% berasal dari Kabupaten Sigi.

Tabel 1. Distribusi Responden menurut wilayah penelitian implementasi pemberian Vitamin A bagi ibu nifas

\begin{tabular}{lcc}
\hline \multicolumn{1}{c}{ Wilayah } & N & \% \\
\hline Kota Palu & 310 & 80,7 \\
Palu Utara & 101 & 26,3 \\
Palu Timur & 27 & 7,0 \\
Palu Barat & 23 & 6,0 \\
Palu Selatan & 50 & 13,0 \\
Mantikulore & 109 & 28,4 \\
Sigi & 74 & 19,3 \\
Biromaru & 24 & 6,3 \\
Dolo & 50 & 13,0 \\
\hline Jumlah & 384 & 100 \\
\hline Sumber: & &
\end{tabular}

Sumber: Data Primer, 2017 
Tabel 2. Karakteristik Responden penelitian implementasi pemberian Vitamin A bagi ibu nifas di Kota Palu dan Kabupaten Sigi

\begin{tabular}{|c|c|c|}
\hline Karakteristik & $\mathbf{n}$ & $\%$ \\
\hline \multicolumn{3}{|l|}{ Umur } \\
\hline$<20$ tahun & 23 & 6,0 \\
\hline 20-35 Tahun & 310 & 80,7 \\
\hline$>35$ Tahun & 51 & 13,3 \\
\hline \multicolumn{3}{|l|}{ Pendidikan Ibu } \\
\hline Sekolah Dasar & 38 & 9,9 \\
\hline SMP & 77 & 20,1 \\
\hline SMU & 192 & 50,0 \\
\hline Perguruan Tinggi & 77 & 20,1 \\
\hline \multicolumn{3}{|l|}{ Pendidikan Suami } \\
\hline Sekolah Dasar & 27 & 7,0 \\
\hline SMP & 73 & 19,0 \\
\hline SMU & 216 & 56,3 \\
\hline Perguruan Tinggi & 68 & 17,7 \\
\hline \multicolumn{3}{|l|}{ Pekerjaan Ibu } \\
\hline IRT & 311 & 81,0 \\
\hline PNS & 32 & 8,3 \\
\hline Honorer & 16 & 4,2 \\
\hline Swasta & 13 & 3,4 \\
\hline Pedagang & 8 & 2,1 \\
\hline Pegawai Bank & 2 & 0,5 \\
\hline Petani & 1 & 0,3 \\
\hline Buruh Harian & 1 & 0,3 \\
\hline \multicolumn{3}{|l|}{ Pekerjaan Suami } \\
\hline Wiraswasta & 142 & 37,0 \\
\hline Pedagang & 58 & 15,1 \\
\hline PNS & 48 & 12,5 \\
\hline Buruh Harian & 46 & 12,0 \\
\hline Petani & 21 & 5,5 \\
\hline Buruh Bulanan & 21 & 5,5 \\
\hline Honorer & 16 & 4,2 \\
\hline Sopir & 14 & 3,6 \\
\hline Nelayan & 5 & 1,3 \\
\hline Ojek & 4 & 1,0 \\
\hline Satpam & 2 & 0,5 \\
\hline Tidak Bekerja & 2 & 0,5 \\
\hline Tukang Jahit & 1 & 0,3 \\
\hline Pegawai Bank & 1 & 0,3 \\
\hline Pelaut & 1 & 0,3 \\
\hline Montir & 1 & 0,3 \\
\hline TNI/Polri & 1 & 0,3 \\
\hline
\end{tabular}

Sumber: Data Primer, 2017

Sebagian besar responden berumur 20-35 tahun $(80,7 \%)$, setengahnya menyelesaikan pendidikan SMU (50\%) demikian pula dengan suami lebih dari setengahnya juga berpendidikan SMU (56,3\%). Dominan ibu berperan sebagai Ibu rumah tangga (IRT) sebanyak $81,0 \%$. Sementara suami paling banyak bekerja sebagai wiraswasta $(37,0 \%)$. dan sebagai pedagang $(15,1 \%)$.
Tabel 3. Implementasi pemberian Vitamin A bagi ibu Nifas di Kota Palu dan Kabupaten Sigi

\begin{tabular}{|c|c|c|}
\hline Implementasi & $\mathbf{n}$ & $\%$ \\
\hline \multicolumn{3}{|l|}{ Pemberian Vitamin A } \\
\hline Menerima & 130 & 33,9 \\
\hline Tidak Menerima & 254 & 66,1 \\
\hline \multicolumn{3}{|l|}{$\begin{array}{l}\text { Jumlah Vitamin A yang } \\
\text { diterima }\end{array}$} \\
\hline Satu & 43 & 33,1 \\
\hline Dua & 87 & 66,9 \\
\hline \multicolumn{3}{|l|}{$\begin{array}{l}\text { Petugas Kesehatan yang } \\
\text { memberikan Vitamin A }\end{array}$} \\
\hline Bidan & 124 & 95,4 \\
\hline Petugas Gizi & 2 & 1,5 \\
\hline Dokter & 4 & 3,1 \\
\hline \multicolumn{3}{|l|}{ Waktu Pemberian Vitamin A } \\
\hline Segera Setelah Melahirkan & 99 & 76,2 \\
\hline 6 Jam Setelah Melahirkan & 16 & 12,3 \\
\hline 1 hari Setelah Melahirkan & 12 & 9,2 \\
\hline 2 hari Setelah Melahirkan & 1 & 0,8 \\
\hline 3 hari Setelah Melahirkan & 2 & 1,5 \\
\hline \multicolumn{3}{|l|}{ Cara Mengasup Vitamin A } \\
\hline 1 Kapsul Saja & 46 & 35,4 \\
\hline 2 Kapsul Sekaligus & 10 & 7,7 \\
\hline $\begin{array}{l}1 \text { Kapsul setiap hari pertama } \\
\text { dan } 1 \text { kapsul hari berikutnya }\end{array}$ & 74 & 56,9 \\
\hline \multicolumn{3}{|l|}{ Suplemen Vitamin lainnya } \\
\hline Ya & 141 & 36,7 \\
\hline Tidak & 243 & 63,3 \\
\hline
\end{tabular}

Sumber: Data Primer, 2017

Tabel 4. Distribusi Morbiditas Responden dan Anak Responden pada Implementasi pemberian Vitamin A bagi ibu nifas di Kota Palu dan Kabupaten Sigi

\begin{tabular}{lcc}
\hline \multicolumn{1}{c}{ Morbiditas } & n & $\mathbf{\%}$ \\
\hline Ibu & 83 & 21,6 \\
Batuk & 61 & 15,9 \\
Demam & 24 & 6,3 \\
Diare & 18 & 4,7 \\
ISPA & 1 & 0,3 \\
Campak & & \\
Anak & 119 & 31,0 \\
Batuk & 107 & 27,9 \\
Demam & 49 & 12,8 \\
ISPA & 17 & 4,4 \\
Diare & 6 & 1,6 \\
Penyakit Lain & 2 & 0,5 \\
Campak & & \\
\hline Sar Dan
\end{tabular}

Sumber: Data Primer, 2017

Tabel 3 menunjukkan bahwa responden yang menerima Kapsul Vitamin A sebanyak $33,9 \%$. Bidan merupakan profesional kesehatan yang paling berperan dalam pemberian Vitamin A ibu nifas $(95,4 \%)$. 
Tabel 5. Distribusi Merek Minyak Goreng yang diasup oleh Responden pada Implementasi pemberian Vitamin A bagi ibu nifas di Kota Palu dan Kabupaten Sigi

\begin{tabular}{lcc}
\hline \multicolumn{1}{c}{ Minyak Goreng } & n & \% \\
\hline Terfortifikasi Vitamin A & & \\
Bimoli & 107 & 27,9 \\
Filma & 6 & 1,6 \\
Fortune & 22 & 5,7 \\
Kunci mas & 147 & 38,3 \\
Masku & 1 & 0,3 \\
Sanco & 6 & 1,6 \\
Sania & 11 & 2,9 \\
Sedap & 2 & 0,5 \\
Tropikana & 2 & 0,5 \\
Tidak Terfortifikasi Vitamin A & & \\
Minyak Curah & 60 & 15,6 \\
Minyak kampung & 20 & 5,2 \\
\hline Sumber: Data Primer, 2017 & &
\end{tabular}

Sumber: Data Primer, 2017

Dari 130 orang, responden yang segera mengonsumsi vitamin A setelah melahirkan sebesar 76,2\%, 6 jam setelah melahirkan $12,3 \%$. Jumlah vitamin A yang diasup secara lengkap 2 kapsul per orang sebesar $66,9 \%$. Cara mengonsumsinya pada umumnya sudah benar yaitu 1 kapsul hari pertama dan 1 kapsul hari berikutnya sebesar $56,9 \%$.

Pada tabel 4. Ibu yang mengalami batuk sebanyak $21,6 \%$ demam $15,9 \%$ dan diare $(6,3 \%)$ Sementara kejadian batuk pada anak sebesar 31,0\%, kejadian demam 27,9\% dan diare $(4,4 \%)$. Penelitian ini dilaksanakan pada bulan agustus dan September dimana pada bulan itu terjadi musim pancaroba sehingga kejadian batuk dan demam cukup tinggi. Pada bulan Agustus pemerintah melaksanakan program bulan vitamin A.

Pada tabel 5. Asupan minyak goreng yang telah terfortifikasi vitamin A sebanyak 79,2\% dan selebihnya yang belum terfortifikasi sebesar 20,8\%. Informasi ini menunjukkan bahwa meskipun pemberian vitamin A di Kota Palu dan Kabupaten Sigi baru 33,3\% namun asupan vitamin A dalam minyak goreng terfortifikasi sudah cukup baik.

Tabel 6. Hubungan Pendidikan Responden dengan Asupan Kapsul Vitamin A pada Implementasi pemberian Vitamin A bagi ibu nifas di Kota Palu dan Kabupaten Sigi

\begin{tabular}{|c|c|c|c|c|c|c|}
\hline \multirow{3}{*}{ Pendidikan } & \multicolumn{4}{|c|}{ Asupan Vitamin A Nifas } & \multirow{3}{*}{ Jumlah } & \multirow{3}{*}{ p-value } \\
\hline & \multicolumn{2}{|c|}{ Ya } & \multicolumn{2}{|c|}{ Tidak } & & \\
\hline & n & $\%$ & $\mathbf{n}$ & $\%$ & & \\
\hline Sekolah Dasar & 6 & 15,8 & 32 & 84,2 & 38 & \\
\hline SMP & 20 & 26,0 & 57 & 74,0 & 77 & \\
\hline SMU & 75 & 39,1 & 117 & 60,9 & 192 & 0,015 \\
\hline Perguruan Tinggi & 29 & 37,7 & 48 & 62,3 & 77 & \\
\hline Jumlah & 130 & 33,9 & 254 & 66,1 & 384 & \\
\hline
\end{tabular}

Sumber: Data Primer, 2017

Tabel 6 menunjukkan bahwa tingkat pendidikan responden juga sangat berpengaruh terhadap asupan vitamin A masa nifas. Semakin tinggi Pendidikan semakin tinggi persentase responden yang mengasup Vitamin A. hasil uji chi Square menunjukkan nilai p-value sebesar 0,015 yang berarti ada hubungan antara Pendidikan dengan asupan vitamin A ibu Nifas.

\section{PEMBAHASAN}

Pelaksanaan penelitian Implementasi pemberian Vitamin A Ibu Nifas di Kota Palu dan Kabupaten Sigi mulai 02 Agustus hingga 15 September 2017. Peneliti dibantu oleh 11 enumerator mengumpulkan data 384 responden yang tersebar pada 7 wilayah kerja puskesmas.
Pada umumnya responden masih dalam kelompok usia reproduktif 20-35 tahun sebesar $80,7 \%$. Berpendidikan sekolah menengah umum 50\%, hanya 9,9 yang berpendidikan sekolah dasar. Bekerja sebagai ibu rumah tangga $81,0 \%$ PNS 8,3\%. Suami responden yang bekerja disektor swasta $37,0 \%$ dan sebagai PNS $12,5 \%$.

Hasil penelitan menunjukkan dari 384 responden Implementasi pemberian Vitamin A Ibu Nifas di Kota Palu dan Kabupaten Sigi sebesar 33,3\%. Implementasi pemberian vitamin A di wilayah penelitian masih rendah dibanding Penelitian Sandjaja \& Ridwan (2012) yang menggunakan data sekunder Riskesdas 2010 dimana cakupan suplementasi kapsul 
Vitamin A pada ibu rata-rata sebesar 56,1 persen dan bervariasi antara provinsi. Cakupan antara perkotaan yaitu sebesar 61,4 persen $^{(15)}$.

Faktor yang cukup berpengaruh dalam pemberian vitamin A ibu nifas ini adalah faktor pendidikan. Tabulasi silang antara Pendidikan Responden dengan Asupan Vitamin A menunjukkan kecenderungan semakin tinggi pendidikan semakin tinggi pula asupan kapsul Vitamin A ibu nifas ( $p$-value $=0,015$ ). Sejalan dengan penelitian ini, Sandjaja \& Ridwan (2012) juga menunjukkan hasil bahwa faktor yang memengaruhi cakupan vitamin A pada ibu nifas adalah mendapatkan pelayanan neonatus, pemberian tablet tambah darah, ANC, imunisasi TT, pendidikan ibu tamat SD, tetapi umur dan status perkawinan tidak memengaruhi cakupan $^{(15)}$.

Menurut Permenkes RI Nomor 21 Tahun 2015 Program Pemberian Vitamin A di Indonesia bagi Nifas adalah pemberian Kapsul Merah (200.000 SI) sebanyak 2 kali yang diberikan setelah melahirkan. Karakteristik pemberian vitamin A di wilayah penelitian menunjukkan bahwa dari 130 responden yang segera mengonsumsi vitamin A Setelah Melahirkan sebesar $76,2 \%$, setelah 6 jam melahirkan 12,3\%, 1 hari Setelah Melahirkan sebesar 9,2\%, 2 hari Setelah Melahirkan sebesar 0,8 dan 3 hari Setelah Melahirkan sebesar 1,5\%. Semetara itu jumlah vitamin A yang diasup secara lengkap adalah sebanyak 84 orang atau dari 130 orang $(66,9 \%)$. Tabulasi silang antara jumlah Vitamin A yang diasup dengan cara mengonsumsinya pada umumnya sudah benar yaitu 1 kapsul hari pertama dan 1 kapsul hari berikutnya sebesar $56,9 \%$ dari jumlah responden yang mengonsumsi 2 kapsul vitamin A masa nifas.

Senada dengan penelitian Permaesih \& Rosmalina (2008) di Serang yang menyarankan agar pemberian Vitamin A 2 kapsul diberikan pada hari ke 3-7 setelah pemberian kapsul vitamin A yang pertama, agar kadar vitamin A dalam AS1 dapat bertahan pada nilai lebih tinggi dalam waktu yang lebih lama. Namun harus tetap diingat, pemberian kapsul vitamin A yang pertama diberikan secepatnya sebelum 1 minggu setelah melahirkan ${ }^{(16)}$.

Profesi kesehatan yang paling berperan dalam pemberian Vitamin A ibu nifas adalah
Bidan $(95,4 \%)$ karena penolong persalinan utama di wilayah penelitian. Sejalan dengan penelitian Dewi, Hakimi \& Suhadi (2010) yang menunjukkan bahwa peran bidan di desa mempunyai hubungan yang bermakna dengan pencapaian cakupan pemberian kapsul vitamin A pada ibu nifas ${ }^{(17)}$. Pelajaran dari penelitian di Sleman pada 47 bidan desa tentang faktorfaktor yang berhubungan dengan program pemberian kapsul vitamin A pada ibu nifas oleh bidan desa. Dari penelitian faktor yang diteliti bekerja berdasarkan pedoman, sumber daya, pengawasan, komunikasi, sikap pelaksana dan dukungan lingkungan persentase terbesar faktor lingkungan berturut mendukung bidan sebagai implementasi pelaksana program $(74,5 \%)$ sangat berpengaruh dalam mendukung pelaksanaan program, pengawasan pemangku kepentingan $(63,8 \%)$ bidan merasa kurang pengawasan berjalan dengan baik, faktor pedoman dari program $(61,7 \%)$, komunikasi antara program kerja manajer $(61,7 \%)$, faktor sikap pelaksana program $(53,2 \%)$, dan faktor sumber daya dari program $(51,1 \%)$. Pelaksanaan vitamin A program suplementasi untuk ibu pasca-melahirkan oleh bidan di wilayah Kabupaten Sleman Kesehatan kantor umumnya dilihat dari enam faktor yang masih di bawah standar yaitu sebesar 53,2\%. Responden yang menganggap bagian dari pelaksanaan program suplementasi vitamin A untuk postpartum ibu sudah baik ${ }^{(18)}$.

Meskipun cakupan masih relatif rendah hanya $33,9 \%$, namun ibu yang mengonsumsi minyak goreng yang telah difortifikasi Vitamin A sudah cukup baik yaitu sebesar $78,4 \%$. Hal ini sangat membantu mengingat asupan dari vitamin A program pemerintah rendah. Pelajaran dari penelitian Permaesih menunjukkan bahwa dari Ibu nifas dengan yang dipilih secara acak untuk menerima minyak goreng yang difortifikasi atau tidak difortikasi selama 80 hari dan diikuti periode "wash out" selama 10 hari. Setelah pelaksanaan intervensi selesai, ditemukan rerata kadar retinol dalam Air Susu Ibu pada kedua kelompok menurun, masing masing 3,6 $\mu \mathrm{g} / \mathrm{dL}$ untuk kelompok fortifikasi dibandingkan dengan $5,3 \mu \mathrm{g} / \mathrm{dL}$ pada kelompok tidak fortifikasi. Tidak ada perbedaan rerata kadar retinol yang nyata pada kedua kelompok tersebut. Penelitian Permaesih menunjukkan bahwa pada kelompok yang 
memperoleh minyak goreng yang difortifikasi sedikit lebih menguntungkan jika dibandingkan dengan kelompok yang mendapat minyak yang tidak difortifikasi, oleh karena penurunan kadar Vitamin A nya lebih kecil ${ }^{(19)}$. Minyak yang diperkaya meningkatkan asupan vitamin A, memberikan kontribusi rata-rata $29 \%$ dari asupan gizi yang direkomendasikan setiap hari untuk ibu menyusui. Rekomendasi asupan gizi dan hubungan antara asupan vitamin dan serum retinol memberikan kemungkinan yang kuat akan fortifikasi minyak yang berdampak pada status vitamin A pada wanita Indonesia ${ }^{(20)}$. Sementara penelitian di Maroko menunjukkan bahwa kombinasi suplementasi dan fortifikasi memiliki dampak yang lebih berkelanjutan pada konsentrasi retinol susu daripada suplementasi saja, yang tidak memiliki dampak berkelanjutan pada konsentrasi Vitamin A susu. Pendekatan fortifikasi tampaknya lebih efektif untuk mempertahankan konsentrasi ASI yang cukup di antara wanita Maroko yang menyusui. Fortifikasi tampaknya menjadi solusi jangka panjang untuk masalah defisiensi Vitamn A, terutama di kalangan wanita di komunitas berpenghasilan rendah ${ }^{(21)}$.

\section{KESIMPULAN DAN SARAN}

Implementasi pemberian Vitamin A Ibu Nifas di Kota Palu dan Kabupaten Sigi sebesar $33,3 \%$. Bidan merupakan profesional Kesehatan yang paling berperan dalam pemberian Vitamin A ibu nifas (95,4\%). Dari 130 orang, responden yang segera mengonsumsi vitamin A setelah melahirkan sebesar 76,2\%, 6 jam setelah melahirkan $12,3 \%$. Jumlah vitamin A yang diasup secara lengkap 2 kapsul per orang sebesar $66,9 \%$. Cara mengonsumsinya pada umumnya sudah benar yaitu 1 kapsul hari pertama dan 1 kapsul hari berikutnya sebesar $56,9 \%$. Disarankan agar pemberian kapsul Vitamin A Ibu Nifas tetap dijalankan terutama pada kelompok rentan yaitu ibu yang berpendidikan dan berpendapatan rendah. Temuan ini dapat disosialisasikan sebagai upaya mencegah kekurangan Vitamin A pada ASI ibu yang menyusui. Konsumsi minyak goreng terfortifikasi vitamin A dapat membantu memenuhi kebutuhan vitamin A pada ibu nifas terutama di kalangan wanita di komunitas berpenghasilan rendah.

\section{UCAPAN TERIMA KASIH}

Terima kasih kepada Kepala Badan PPSDM dan Direktur Poltekkes Kemenkes Palu atas dana penelitian tahun 2017, Kepada Kepala Dinas Kesehatan Kota Palu dan Kabupaten Sigi atas ijin penelitian yang telah diberikan serta kepada seluruh responden peneltian ini yang telah terlibat.

\section{DAFTAR PUSTAKA}

1. Oliveira JM East CE AR. Vitamin A supplementation for postpartum women (Cochrane Review). (Review content assessed as up-to-date: 1 December 2015). 2016;(3).

2. Yu K, Xue Y, Zhao W, Zhao A, Li W, Zhang $\mathrm{Y}$, et al. Translation of nutrient recommendations into personalized optimal diets for Chinese urban lactating women by linear programming models. BMC Pregnancy Childbirth. 2018 Sep;18(1):379.

3. Daniels L, Gibson RS, Diana A, Haszard JJ, Rahmannia S, Luftimas DE, et al. Micronutrient intakes of lactating mothers and their association with breast milk concentrations and micronutrient adequacy of exclusively breastfed Indonesian infants. Am J Clin Nutr. 2019 Aug;110(2):391-400.

4. Rahmannia S, Diana A, Luftimas DE, Gurnida DA, Herawati DMD, Houghton LA, et al. Poor dietary diversity and low adequacy of micronutrient intakes among rural Indonesian lactating women from Sumedang district, West Java. PLoS One. 2019;14(7):e0219675.

5. Matamoros N, Visentin S, Ferrari G, Falivene M, Fasano V, González HF. Vitamin A content in mature breast milk and its adequacy to the nutritional recommendations for infants. Arch Argent Pediatr. 2018 Apr;116(2):146-8.

6. Gurgel CSS, Grilo EC, Lira LQ, Assunção DGF, Oliveira PG, Melo LRM de, et al. Vitamin A nutritional status in high- and low-income postpartum women and its effect on colostrum and the requirements of the term newborn. J Pediatr (Rio J). 2018;94(2):207-15.

7. Soares MM, Silva MA, Garcia PPC, Silva LS da, Costa GD da, Araújo RMA, et al. Efect of vitamin A suplementation: a systematic review. Cien Saude Colet. 2019 Mar;24(3):827-38.

8. Gogia S, Sachdev HS. Vitamin A supplementation for the prevention of morbidity and mortality in infants six 
months of age or less. Cochrane database Syst Rev. 2011 Oct;(10):CD007480.

9. Tomiya MTO, de Arruda IKG, da Silva Diniz A, Santana RA, da Silveira KC, Andreto LM. The effect of vitamin A supplementation with 400000 IU vs 200000 IU on retinol concentrations in the breast milk: A randomized clinical trial. Clin Nutr. 2017 Feb;36(1):100-6.

10. World Health Organization. Guideline. Vitamin A supplementation in postpartum women. Geneva, Switzerland; 2011. 26 p.

11. Kementrian Kesehatan RI. Peraturan Menteri Kesehatan Republik Indonesia Nomor 21 Tahun 2015 Tentang Standar Kapsul Vitamin A Bagi Bayi, Anak Balita, Dan Ibu Nifas. 2015.

12. Maryani D. Suplementasi Vitamin a Bagi Ibu Post Partum Dan Bayi. OKSITOSIN J Ilm Kebidanan. 2019;6(1):9-15.

13. Cruz S, da Cruz SP, Ramalho A. Impact of Vitamin A Supplementation on Pregnant Women and on Women Who Have Just Given Birth: A Systematic Review. J Am Coll Nutr. 2018;37(3):243-50.

14. Martins TM, Ferraz IS, Daneluzzi JC, Martinelli CEJ, Del Ciampo LA, Ricco RG, et al. Impact of maternal vitamin A supplementation on the mother-infant pair in Brazil. Eur J Clin Nutr. 2010 Nov;64(11):1302-7.

15. Sandjaja Endi SR. Cakupan Suplementasi Kapsul Vitamin A Pada Ibu Masa Nifas dan Faktor-Faktor yang Memengaruhi di Indonesia Analisis Data Riskesdas 2010. Bul Penelit Sist Kesehat. 2012;(Vol 15, No
1 Jan (2012)).

16. Permaesih D, Rosmalina Y. Kandungan Vitamin A Asi Ibu Nifas Di Kabupaten Serang. Nutr Food Res. 2008;31(1).

17. Dewi VK, Hakimi M, Suhadi A. Peran Bidan di Desa dan Cakupan Pemberian Kapsul Vitamin A pada Ibu Nifas. Ber Kedokt Masy. 2010;26(2):63-70.

18. Susilowati A, Sriatmi A, Arso SP. FaktorFaktor yang Berhubungan Dengan Program Pemberian Kapsul Vitamin A Pada Ibu Nifas oleh Bidan Desa Di Wilayah Dinas Kesehatan Kabupaten Sleman. J Kesehat Masy (e-Journal); Vol 3, No 2 April. 2015 Apr 1;3(2):30-40.

19. Permaesih D, Rosmalina Y, Tanumiharjo SA. Pengaruh Konsumsi Minyak Goreng yang Difortifikasi Vitamin A Terhadap Kadar Retinol Air Susu Ibu. Gizi Indones. 2014 Sep 30;37(2):119.

20. Sandjaja, Jus'at I, Jahari AB, Ifrad, Htet MK, Tilden RL, et al. Vitamin A-fortified cooking oil reduces vitamin A deficiency in infants, young children and women: results from a programme evaluation in Indonesia. Public Health Nutr. 2015 Oct;18(14):251122.

21. Atalhi N, El Hamdouchi A, Barkat A, Elkari K, Hamrani A, El Mzibri M, et al. Combined consumption of a single high-dose vitamin A supplement with provision of vitamin A fortified oil to households maintains adequate milk retinol concentrations for 6 months in lactating Moroccan women. Appl Physiol Nutr Metab = Physiol Appl Nutr Metab. 2020 Mar;45(3):275-82. 